\title{
Are the Judicial Reports Prepared in Emergency Services Consistent with Those Prepared in Forensic Medicine Department of a University Hospital?
}

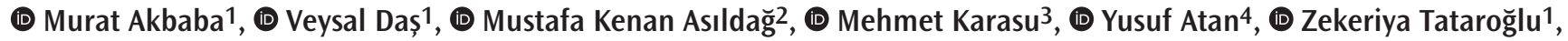 \\ (1) Seval Kul ${ }^{5}$
}

\author{
1Department of Forensic Medicine, Gaziantep University Faculty of Medicine, Gaziantep, Turkey \\ 2Gaziantep Branch Office of İstanbul Forensic Medicine Institute, Gaziantep, Turkey \\ ${ }^{3}$ Division of Forensic Medicine, Dr. Ersin Arslan Training and Research Hospital, Gaziantep, Turkey \\ ${ }^{4}$ Çankırı Branch Office of İstanbul Forensic Medicine Institute, Çankırı, Turkey \\ ${ }^{5}$ Department of Biostatistics, Gaziantep University Faculty of Medicine, Gaziantep, Turkey
}

\begin{abstract}
Aim: This study aimed to analyze the judicial reports prepared in emergency services and to emphasize the importance of forensic medicine education for the physicians working at these services and the reflection of the situation to the judicial authorities.

Materials and Methods: Reports prepared by Forensic Medicine Department of Gaziantep University Medical Faculty were accepted as the gold standard and the judicial reports of the same patients prepared in emergency services were compared retrospectively.

Results: Most reports were found to be prepared as temporary reports. The concepts of general condition, consciousness, life-threatening clinical status and simple medical interventions were frequently mentioned, while other concepts were not mentioned. The success rate of identifying cases with and without life-threatening clinical status in emergency services was $83.49 \%$ and $85.52 \%$, respectively. The success rate of identifying cases that could and could not be treated with simple medical intervention was $84.20 \%$ and $58.62 \%$, respectively.

Conclusion: It has been determined that the problems in both mentioning basic concepts and accurate report writing cannot be solved in the judicial reports organized in emergency departments. In order to protect themselves, physicians have a tendency to report the consequences more severe than they actually are. However, it should be kept in mind that this tendency may not protect the physician, but also may cause additional legal problems.
\end{abstract}

Keywords: Judicial report errors, emergency service, forensic medicine

\section{Introduction}

Judicial report writing is more than an act of writing to influence the court. It must follow ethical guidelines and practice principles as well as the recommended style and formatting. The most important principle is to remain impartial and not advocate for the referral source (1).
One of the responsibilities of the physicians working in emergency services is to report judicial cases to the authorities and prepare case reports $(2,3)$. The reports prepared by these physicians play an important role in the accurate and rapid progression of judicial procedures (4). Today, the concept of medical error goes beyond examining the physician's ability to interpret information to analyze whether they can accurately utilize the 
available methods and techniques (5). Since the number of forensic specialists in Turkey is insufficient, most judicial cases are examined by physicians who have specialized in areas other than forensic medicine $(6,7)$. In addition to the insufficient importance given to forensic medicine courses during medical education, long working hours, inappropriate conditions for physicians and high number of patients make inaccurate judicial reports unavoidable $(2-4,8)$.

In our country, because of insufficient forensic medicine education in medical faculties and in-service training in public and private hospitals, the insight of emergency physicians in preparing judicial reports cannot be developed effectively, and the consequent errors might have irreversible effects $(9,10)$. Considering problems such as limited information obtained from emergency service patients and limited possible examinations, physicians tend to prepare temporary reports (11-13). However, this does not protect physicians and, on the contrary, leads to prolonged judicial procedures and unnecessary document traffic (14).

In this study, we examined judicial reports referred to Forensic Medicine Department of Gaziantep University Medical Faculty for a final report and investigated the context and errors in these reports. Therefore, we aimed to emphasize the importance of judicial medicine education for emergency physicians and how this is reflected on the cases presented to the judicial authorities.

\section{Materials and Methods}

The study population consisted of 631 judicial reports that were prepared in emergency services and that were referred to the Forensic Medicine Department of Gaziantep University between January 1, 2012 - January 1, 2015. The judicial reports prepared by emergency physicians in our region were examined in terms of fundamental criteria, such as whether the present lesions were life-threatening, if they could be treated by simple medical intervention, if the criterion of permanent scar on the face was mentioned and the effects of a bone fracture on vital functions. These reports were also examined in terms of error rates. This study was designed as a descriptive and retrospective study, and the judicial reports that were prepared by our department and sent to judicial authorities were considered as gold standard.

The ethical committee approval of our study was obtained from the Ethical Committee of Clinic Researches of Gaziantep University (approval number: 2016/168).

\section{Statistical Analysis}

Numbers and percentages were given as descriptive statistics. Sensitivity, specificity and 95\% confidence intervals (Cls) were calculated using Medcalc Version 15.11 to evaluate the correct classification capability of the reports prepared by emergency services. The cases where $50 \%$ of data did not fall within the $\mathrm{Cl}$ of sensitivity and specificity were considered statistically significant.

\section{Results}

Eighty percent $(n=505)$ of the cases were male and $20 \%(n=126)$ were female. The mean age was 28.41 years $( \pm 16.64)$; the youngest case was a 10-month-old female and the oldest case was an 82-year-old male. It was determined that the majority of the reports (92.1\%) were prepared as temporary reports. While the general condition, consciousness, life-threatening clinical status and simple medical intervention concepts were frequently mentioned, cooperation was only mentioned in 62 cases, bone fracture in one case and permanent facial scar in three cases. In the temporary reports, emergency physicians stated that lesions involved life-threatening clinical status in 166 cases (26.3\%), that the lesions could not be treated by simple medical intervention in 437 (69.3\%) cases and that they requested an analysis for alcohol use in $72(11.4 \%)$ cases (Table 1).

Based on the reports prepared by emergency services, the types of events were as follows: traffic accidents in 210 cases (33.3\%), battery/physical violence in 188 cases (29.8\%), penetrating stab wounds in 115 cases (18.2\%), firearm injuries in 54 cases (8.6\%), falling from a height in 14 cases (2.2\%), industrial accidents in 10 cases $(1.6 \%)$, suicide attempt in 5 cases $(0.8 \%)$ and undefined injuries in 35 cases (5.5\%).

Excluding the four cases where life-threatening criteria were not questioned (although there was a life-threatening clinical status), it was determined that, from the aspect of forensic medicine practice, the "life-threatening" statement was accurate in 91 and inaccurate in 14 final and temporary reports prepared in the emergency services. On the other hand, in 75 cases, the report indicated a life-threatening clinical status although there was no life-threatening clinical status. The absence of life-threatening clinical status was accurately diagnosed in 429 cases, and this criterion was not discussed in 14 cases with no life-threatening clinical status. The success rate of emergency services in identifying cases that involved life-threatening clinical status was 83.49\% (95\% Cl=75.16-89.91) and in identifying the absence of life-threatening clinical status was $85.52 \%(95 \% \mathrm{Cl}=82.19-88.44)$ (Table 2).

The final and temporary reports prepared by emergency services were compared after excluding 23 cases in which the criterion of "simple medical intervention" was not questioned by the judicial authorities. Emergency physicians specified that the lesions could not be treated by simple medical intervention in 
341 cases and that the lesions could be treated in 109 cases. This criterion was not discussed in 29 cases, in which the lesions could be treated by simple medical intervention in 19 cases and could not be treated in 10 cases. The reports were prepared incorrectly in 129 cases. The lesions that could be treated by simple medical intervention were reported to be not treatable by simple medical intervention in 84 cases, and those that could not be treated by simple medical intervention were reported to be treatable in 45 cases. The success rate of emergency services in accurately identifying the cases that could not be treated by simple medical intervention was $84.20 \%(95 \% \mathrm{Cl}=80.27-87.61)$ and in identifying those that could be treated by simple medical intervention was 58.62\% (95\% Cl=51.51-65.47) (Table 2).

Considering the relationship between event types and lifethreatening conditions, the reports accurately prepared by emergency services included 166 reports for traffic accidents, 171 reports for physical violence/battery, 96 reports for penetrating stab injuries and 41 reports for firearm injuries. On the other hand, the inaccurate reports included 42 reports for traffic accidents, 10 reports for physical violence/battery, 15 reports for penetrating stab injuries and 11 reports for firearm injuries. The number of reports where these parameters were not discussed was two for traffic accidents, five for physical violence/battery and one for firearm injuries (Table 3). Considering event types with a limited number of cases, reports for falling from a height indicated that there was life-threatening clinical status in four of 14 cases and no life-threatening clinical status in five cases, and three of the five cases without life-threatening clinical status were incorrectly reported and no opinion was reported in two cases. Of the 10 industrial accidents, a life-threatening clinical status was reported in two cases and no life-threatening clinical status was reported in eight reports. Of the five suicide attempt cases, there was a life-threatening clinical status in two cases. Two cases with no life-threatening clinical status was accurately diagnosed, whereas, one case with a life-threatening clinical status was inaccurately reported.

Table 1. Demographic data for case reports prepared by emergency services

\begin{tabular}{|c|c|c|c|c|c|}
\hline Parameters & & $\begin{array}{l}\text { Number } \\
\text { [n (\%)] }\end{array}$ & Parameters & & $\begin{array}{l}\text { Number } \\
{[n(\%)]}\end{array}$ \\
\hline \multirow{2}{*}{ Gender } & Female & $126 / 20$ & \multirow{3}{*}{$\begin{array}{l}\text { Life-threatening } \\
\text { clinical status }\end{array}$} & Yes & $166(26.3)$ \\
\hline & Male & $505 / 80$ & & No & 447 (70.8) \\
\hline Age* & Min-max (0-82) & $28.41 \pm 16.64$ & & Not specified & $18(2.9)$ \\
\hline \multirow{3}{*}{ General condition $^{\dagger}$} & Yes & $472 / 74.8$ & \multirow{3}{*}{$\begin{array}{l}\text { Simple medical } \\
\text { treatment }\end{array}$} & Untreatable & 437 (69.2) \\
\hline & No & $148 / 23.5$ & & Treatable & $164(26.0)$ \\
\hline & $N / A$ & $11 / 1.7$ & & Not specified & $30(4.8)$ \\
\hline \multirow{3}{*}{ Consciousness $^{\dagger}$} & Yes & $468 / 74.2$ & \multirow{2}{*}{ Alcohol } & Examined & $72(11.4)$ \\
\hline & No & $152 / 24.1$ & & Unexamined & 559 (88.6) \\
\hline & $\mathrm{N} / \mathrm{A}$ & $11 / 1.7$ & \multirow{3}{*}{ Report type } & Temporary & 581 (92.1) \\
\hline \multirow[t]{3}{*}{ Cooperation $^{\dagger}$} & Yes & $62 / 9.8$ & & Final & $48(7.6)$ \\
\hline & No & $556 / 88.1$ & & Not specified & $2(0.3)$ \\
\hline & $\mathrm{N} / \mathrm{A}$ & $13 / 2.1$ & - & - & - \\
\hline
\end{tabular}

Table 2. Sensitivity and specificity values for vital risk and simple medical intervention

\begin{tabular}{|c|c|c|c|c|c|c|c|}
\hline & \multirow[b]{2}{*}{ LTCS } & \multicolumn{2}{|c|}{$\begin{array}{l}\text { Reports of forensic medicine } \\
\text { department }\end{array}$} & & \multirow[b]{2}{*}{ SMT } & \multicolumn{2}{|c|}{$\begin{array}{l}\text { Reports of forensic medicine } \\
\text { department }\end{array}$} \\
\hline & & Yes & No & & & Untreatable & Treatable \\
\hline \multirow{3}{*}{$\begin{array}{l}\text { Emergency } \\
\text { service reports }\end{array}$} & Yes & 91 & 75 & \multirow{3}{*}{$\begin{array}{l}\text { Emergency } \\
\text { service reports }\end{array}$} & Untreatable & 341 & 84 \\
\hline & No & 14 & 429 & & Treatable & 45 & 109 \\
\hline & Not specified & 4 & 14 & & Not specified & 19 & 10 \\
\hline \multicolumn{4}{|c|}{ Sensitivity $(95 \% \mathrm{Cl})=83.49(75.16-89.91)$} & \multicolumn{4}{|c|}{ Sensitivity $(95 \% \mathrm{Cl})=84.20(80.27-87.61)$} \\
\hline \multicolumn{4}{|c|}{ Specificity $(95 \% \mathrm{Cl})=85.52(82.19-88.44)$} & \multicolumn{4}{|c|}{ Specificity $(95 \% \mathrm{Cl})=58.62(51.51-65.47)$} \\
\hline
\end{tabular}


Considering the relationship between event types and simple medical intervention, it was determined that the number of accurately prepared reports was 158 for traffic accidents, 118 for physical violence/battery, 80 for penetrating stab injuries and 46 for firearm injuries. On the other hand, the number of incorrect reports was 35 for traffic accidents, 53 for physical violence/battery, 30 for penetrating stab injuries and three for firearm injuries. The number of reports that did not discuss these parameters was eight for traffic accidents, nine for physical violence/battery, four for penetrating stab injuries and four for firearm injuries (Table 4). Considering the event types with a limited number of cases, of the 12 cases of falling from a height, it was accurately diagnosed that nine cases could and one case could not be treated by simple medical intervention, while two treatable cases were reported to be untreatable by simple medical intervention. It was reported that cases were accurately identified to be untreatable in 10 industrial accidents and that one case was not identified. In four of five suicide attempt cases, the lesions were reported to be treatable by simple medical intervention in parallel with the report of our department, while one report was written incorrectly by emergency physicians.

Interestingly, in the judicial reports prepared by the emergency services, only one case was reported to have a bone fracture, and the injury was not reported to cause any bone fracture or dislocation. A permanent facial scar was reported in three cases, but one lesion was not within the facial borders and the other was wrongly reported to be a permanent scar (in forensic medical practice, a six-month period is required after which the scar is reassessed and then diagnosed as a permanent scar). The criteria regarding lesions causing a permanent weakening or loss of any of the senses or organs were not discussed in any of the reports.

\section{Discussion}

Today, the concept of expert opinion plays an important role in determining the relationship between the behavior and any consequent damage. Considering the increasing number of law suits filed against physicians, especially in recent years, the

Table 3. Comparison of availability of life-threatening clinical status between the reports prepared by our department and emergency services according to event type

\begin{tabular}{|c|c|c|c|c|c|c|}
\hline \multirow{3}{*}{$\begin{array}{l}\text { Event type } \\
\text { Available } \\
\text { [n (\%)] } \\
\text { Not available [n (\%)] }\end{array}$} & & & & \multicolumn{2}{|c|}{ Reports of forensic medicine department } & \multirow{3}{*}{$\begin{array}{l}\text { Total } \\
\text { [n (\%)] }\end{array}$} \\
\hline & & & & & & \\
\hline & & & & & & \\
\hline \multirow{4}{*}{ Traffic accident } & \multirow{4}{*}{ 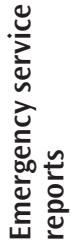 } & \multirow{3}{*}{$\begin{array}{l}\text { Life-threatening } \\
\text { clinical status }\end{array}$} & Available & $40(78.4)$ & $32(20.1)$ & $72(34.3)$ \\
\hline & & & $\mathrm{N} / \mathrm{A}$ & $10(19.6)$ & $126(79.2)$ & $136(64.8)$ \\
\hline & & & Not specified & $1(2.0)$ & $1(0.6)$ & $2(1.0)$ \\
\hline & & Total & & $51(100)$ & $159(100)$ & $210(100)$ \\
\hline & & & Available & $5(71.4)$ & $8(4.5)$ & $13(7.0)$ \\
\hline & $>\frac{5}{2}$ & Life-threatening & $\mathrm{N} / \mathrm{A}$ & $2(28.6)$ & $166(92.7)$ & $168(90.3)$ \\
\hline \multirow{2}{*}{ Physical violence/battery } & 总高 & & Not specified & $0(0.0)$ & $5(2.8)$ & $5(2.7)$ \\
\hline & $\bar{\Psi} \bar{\varpi}$ & Total & & $7(100)$ & $179(100)$ & 186 (100) \\
\hline \multirow{4}{*}{ Penetrating stab injuries } & \multirow{4}{*}{ 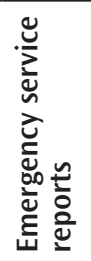 } & \multirow{3}{*}{$\begin{array}{l}\text { Life-threatening } \\
\text { clinical status }\end{array}$} & Available & $22(95.7)$ & $15(16.5)$ & $37(32.5)$ \\
\hline & & & $\mathrm{N} / \mathrm{A}$ & $0(0.0)$ & $74(81.3)$ & $74(64.9)$ \\
\hline & & & Not specified & $1(4.3)$ & $2(2.2)$ & $3(2.6)$ \\
\hline & & Total & & $23(100)$ & $91(100)$ & $114(100)$ \\
\hline \multirow{4}{*}{ Firearm injuries } & \multirow{4}{*}{ 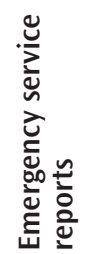 } & \multirow{3}{*}{$\begin{array}{l}\text { Life-threatening } \\
\text { clinical status }\end{array}$} & Available & $11(91.7)$ & $11(26.8)$ & $22(41.5)$ \\
\hline & & & N/A & $0(0.0)$ & $30(73.2)$ & $30(56.6)$ \\
\hline & & & Not specified & $1(8.3)$ & $0(0.0)$ & $1(1.9)$ \\
\hline & & Total & & $12(100)$ & $41(100)$ & $53(100)$ \\
\hline
\end{tabular}


importance of expert opinion in addition to accurate and ontime patient intervention means that physicians need specific training for preparing accurate judicial reports (15). Even though both clinical and judicial reports require good writing skills and extensive experience (16-18), judicial reports have a different purpose, which is reflected in their impact, quality and style $(19,20)$. When conducting a clinical evaluation, the patient is likely the person being tested. Conversely, in a forensic evaluation, the client is usually the court and referral questions are related to psycho-legal issues (21). Another key difference between judicial and clinical reports is the impact of the report. Judicial reports often have more lasting repercussions than clinical reports. The written report, either alone or with accompanying testimony, often significantly influences the outcome of a legal conflict $(16,22)$. Given that a considerable number of applications to emergency services are judicial cases, the preparation of accurate and legally appropriate reports becomes more important $(2,23)$.
In studies carried out on judicial cases referred by emergency services, the most frequent reason for the application is traffic accidents $(3,4,6,9,23-27)$. In the present study, traffic accidents were the most common reason with 210 cases (33.3\%). Despite social awareness-raising efforts and road maintenance works, traffic accidents are still an important problem in our country.

In a study conducted by Turla et al. (24), they reported that there was no information about the general status, consciousness and cooperation in approximately $60 \%$ of judicial reports. In our study, the criteria of general status and consciousness were mainly discussed, although cooperation was not mentioned. This result indicates that the importance given to patient consciousness by the physicians has increased but that the concept of cooperation is not given sufficient importance.

In the present study, only $9.2 \%$ of the reports were prepared as a final report, and this result is consistent with the tendency of emergency services to handwrite temporary reports $(4,26,28,29)$.

Table 4. Comparison of simple medical treatment between the reports prepared by our department and emergency services according to event type

\begin{tabular}{|c|c|c|c|c|c|c|}
\hline \multirow{2}{*}{ Event type } & & & & \multicolumn{2}{|c|}{$\begin{array}{l}\text { Reports of forensic medicine } \\
\text { department }\end{array}$} & \multirow{2}{*}{$\begin{array}{l}\text { Total } \\
{[\mathrm{n}(\%)]}\end{array}$} \\
\hline & & & & $\begin{array}{l}\text { Untreatable } \\
\text { [n (\%)] }\end{array}$ & $\begin{array}{l}\text { Treatable } \\
{[\mathrm{n}(\%)]}\end{array}$ & \\
\hline \multirow{4}{*}{ Traffic accident } & \multirow{4}{*}{ 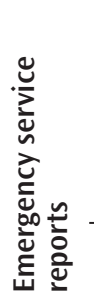 } & \multirow{3}{*}{ 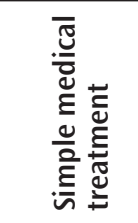 } & Untreatable & $127(87.0)$ & $21(38.2)$ & 148 (73.6) \\
\hline & & & Treatable & $14(9.6)$ & $31(56.4)$ & $45(22.4)$ \\
\hline & & & Not specified & $5(3.4)$ & $3(5.5)$ & $8(4.0)$ \\
\hline & & Total & & $146(100)$ & $55(100)$ & $201(100)$ \\
\hline \multirow{4}{*}{$\begin{array}{l}\text { Physical violence/ } \\
\text { battery }\end{array}$} & \multirow{4}{*}{ 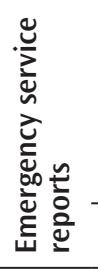 } & \multirow{3}{*}{ 을을 } & Untreatable & 54 (76.1) & $40(36.7)$ & $94(52.2)$ \\
\hline & & & Treatable & $13(18.3)$ & $64(58.7)$ & 77 (42.8) \\
\hline & & & Not specified & $4(5.6)$ & $5(4.6)$ & $9(5.0)$ \\
\hline & & Total & & $71(100)$ & $109(100)$ & $180(100)$ \\
\hline \multirow{4}{*}{$\begin{array}{l}\text { Penetrating stab } \\
\text { injuries }\end{array}$} & \multirow{4}{*}{ 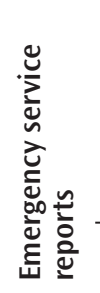 } & \multirow{3}{*}{ 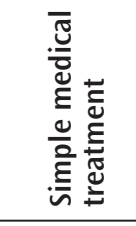 } & Untreatable & $72(80.9)$ & $17(68.0)$ & 89 (78.1) \\
\hline & & & Treatable & $13(14.6)$ & $8(32.0)$ & $21(18.4)$ \\
\hline & & & Not specified & $4(4.5)$ & $0(0.0)$ & $4(3.5)$ \\
\hline & & \multicolumn{2}{|l|}{ Total } & $89(100.0)$ & $25(100.0)$ & $114(100.0)$ \\
\hline \multirow{4}{*}{ Firearm injuries } & \multirow{4}{*}{ 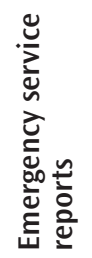 } & \multirow{3}{*}{ 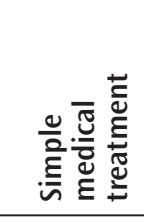 } & Untreatable & $46(90.2)$ & $1(50.0)$ & $47(88.7)$ \\
\hline & & & Treatable & $2(3.9)$ & $0(0.0)$ & $2(3.8)$ \\
\hline & & & Not specified & $3(5.9)$ & $1(50.0)$ & $4(7.5)$ \\
\hline & & Total & & $51(100)$ & $2(100)$ & $53(100)$ \\
\hline
\end{tabular}


In a study by Demirci et al. (30), emergency physicians were given theoretical and practical training on writing judicial reports, and the rate of "temporary report" declined from 55.5\% (prior to training) to $0.5 \%$. Emergency physicians generally prefer not to prepare final reports due to both lack of knowledge and avoidance from legal responsibility. Over time, this leads to spoiling of evidence, prolongation of legal procedures and delay in justice (25). This result was also corroborated in our study and it is necessary to encourage physicians to prepare final reports.

In their study examining a series of 5870 cases, Seviner et al. (25) reported that life-threatening clinical status was discussed in $56.8 \%$ of the reports prepared by emergency services. The reported rated was $80.3 \%$ in the study of Güven et al. (31) in 1296 cases, $91.5 \%$ in the study of Bozkurt (29) in 1218 cases and $97.1 \%$ in our study. Therefore, the inclusion of life-threatening clinical status, which is one of the most fundamental criteria that the judicial reports should include, was quite variable. Although there has been an increase in the rate of discussing this parameter in recent years, actual data indicate that emergency physicians lack a basic knowledge of writing judicial reports.

In previous studies, the rate of incorrect life-threatening clinical status was reported to be $13 \%$ by Serinken et al. (4) and $6.5 \%$ by Türkmen et al. (32). In our study, the life-threatening clinical status was accurately diagnosed in 520 emergency service reports, inaccurately diagnosed in 89 reports and not discussed in 18 reports. The rate of correctly identifying life-threatening clinical status was $83.49 \%$ and identifying the absence of lifethreatening clinical status was $85.52 \%$. This result shows that, beside the fact that there are significant problems in discussing basic criteria in judicial reports prepared in emergency services, there are also important problems in writing the reports and indicating accurate diagnoses. Considering the importance given to life-threatening clinical status under Turkish Penal Law, it is clear that this is a serious problem with significant consequences.

Bozkurt (29) emphasized that the concept of simple medical intervention was discussed in $66 \%$ of judicial reports, and this was $95.2 \%$ in the present study. Moreover, from the aspect of simple medical intervention by emergency services, our study determined that accurate diagnoses were made in 450 cases, misdiagnoses were made in 129 cases and no diagnosis was made in 19 reports. For the cases that could not be treated by simple medical intervention, the success rate of accurately identifying this was $84.20 \%$ and that of identifying the cases that could be treated by simple medical intervention was $58.62 \%$. The success of physicians in identifying the lesions that could be treated by simple medical intervention was $50 \%$, and it was almost the same for non-physician individuals. This remarkable result clearly indicates that, besides the severe knowledge deficiency, the physicians that prepared the judicial reports and stated that the lesions could not be treated by simple medical intervention did so in order to protect themselves and to avoid taking any legal responsibility. However, when a report that has severe consequences for the counterparty is prepared, the physician that prepared the report may have certain legal responsibilities.

Considering the event types from a general aspect, the most accurate reports are written for cases such as falling from a height, industrial accident, suicide attempt, firearm injury and penetrating stub injuries, where the lesions are visible during a physical examination. This rate decreases for blunt trauma cases such as physical violence/battery, traffic accident and lesions of visceral organs, where the lesions are not visible to the naked eye. Some of the reasons for these observations are that physicians do not have information about writing judicial reports, and that they do not have time for a detailed patient examination and writing the report before examining the patient in detail.

\section{Conclusion}

In conclusion, even the scope of judicial reports is very wide, reports prepared by emergency service personnel are expected to accurately and fully describe the lesions, to be written in a more comprehensive language and accurately define the legal concepts such as life-threatening clinical status and simple medical intervention. Because of these important deficiencies, our physicians may be subjected to legal and penal sanctions due to unjust treatments caused by inaccurate reports. Thus, in order to protect physicians from being victimized as a result of their actions and to prevent the victimization of counterparties in a lawsuit, it is necessary to offer students objective-driven education by refining these topics in forensic medical education in medical faculties. It is of great importance to initiate a widespread in-service training campaign by the Ministry of Health, and to repeat training, which will be given by forensic medicine experts, on a regular basis in order to keep abreast with knowledge in this area.

\section{Ethics}

Ethics Committee Approval: The ethical committee approval of our study was obtained from the Ethical Committee of Clinic Researches of Gaziantep University (approval number: 2016/168).

Informed Consent: Retrospective study.

Peer-review: Externally and internally peer-reviewed.

\section{Authorship Contributions}

Surgical and Medical Practices: M.A., V.D., Y.A., Concept: M.A., M.K.A., M.K., Design: M.A., Z.T., Data Collection or 
Processing: M.A., V.D., Analysis or Interpretation: S.K., Literature Search: M.A., M.K., Writing: M.A., Y.A., Z.T.

Conflict of Interest: No conflict of interest was declared by the authors.

Financial Disclosure: The authors declared that this study received no financial support.

\section{References}

1. Young G. Psychiatric/psychological forensic report writing. Int J Law Psychiatry. 2016;49:214-20.

2. Korkmaz T, Kahramansoy N, Erkol Z, Sarıçil F, Kılıç A. Evaluation of the forensic patients presenting to the emergency department and legal reports. Med Bull Haseki. 2012;50:14-20.

3. Küçük E, Günel C. Demographic characteristics of forensic investigation in emergency service. Sakarya Tıp Dergisi. 2016;6:100-5.

4. Serinken M, Türkçüer I, Acar K, Özen M. Evaluation of medicolegal reports written by physicians in the emergency unit with regard to deficiencies and mistakes. Ulus Travma Acil Cerrahi Derg. 2011;17:23-8.

5. Christensen AM, Crowder CM, Ousley SD, Houck MM. Error and its meaning in forensic science. J Forensic Sci. 2014;59:123-6.

6. Güven FMK, Bütün C, Beyaztaș FY, Eren ȘH, Korkmaz I. Evaluation of forensic cases admitted to Cumhuriyet University hospital. Meandros Med Dent J. 2009;10:23-8.

7. Yavuz MF, Yavuz MS. Standardization and deficiencies of forensic reports. Turkiye Klinikleri Journal of Surgical Medical Sciences. 2006;2:28-33.

8. Serinken M, Çımrın A, Ergör A, Cimilli C, Bengi F. Burnout syndrome and emergency service physicians. Toplum ve Hekim. 2002;17:358-65.

9. Fedakar R, Aydiner AH, Ercan I. A comparison of "life threatening injury" concept in the Turkish Penal Code and trauma scoring systems. Ulusal Travma Acil Cerrahi Derg. 2007;13:192-8.

10. Yavuz MS, Aydın S. Forensic cases and reports in primary health care. Turkish Journal of Family Practice. 2007;8:30-3.

11. Hon KL, Leung TF, Cheung KL, Nip SY, Ng J, Fok TF et al. Severe childhood injuries and poisoning in a densely populated city: Where do they occur and what type? J Crit Care. 2010;25:175.

12. Sever M, Saz EU, Koșargelir M. An evaluation of the pediatric medico-legal admissions to a tertiary hospital emergency department. Ulus Travma Acil Cerrahi Derg. 2010;16:260-7.

13. Çetinel Y, Gülalp B, Karagün Ö, Örel Ö, Seçkin TD, Aldinç H, et al. Pediatric cases that composed temporary legal report; whom? when? JAEM. 2013;12:113-7.

14. Çolak B, Demirbaș I, Albayrak Ü. The importance of temporary forencis reports. STED Dergisi. 2005;14:161-4.

15. Naveen S, Kumar MV. Preparing medico legal report in clinical practice. Indian J Surg. 2013;75:47-9.

16. Griffith EE, Stankovic A, Baranoski M. Conceptualizing the forensic psychiatry report as performative narrative. J Am Acad Psychiatry Law. 2009;38:32-42.
17. Howes LM, Kirkbride KP, Kelty SF, Julian R, Kemp N. The readability of expert reports for non-scientist report-users: Reports of forensic comparison of glass. Forensic Sci Int. 2014;236:54-66.

18. Sand K, Eik-Nes NL, Loge JH. Readability of informed consent documents (1987-2007) for clinical trials: a linguistic analysis. J Empir Res Hum Res Ethics. 2012;7:67-78.

19. Brannick ME. Guidelines for Forensic Report Writing: Helping Trainees Understand Common Pitfalls to Improve Reports. 2015

20. Kariyawasam U. The impact of peer review on paediatric forensic reports. J Forensic Leg Med. 2016;43:42-7.

21. Karson M, Nadkarni L. Principles of forensic report writing: American Psychological Association. 2013.

22. Reid WH. Writing reports for lawyers and courts. J Psychiatr Pract. 2011;17:355-9.

23. Yavuz M, Baștürk P, Yavuz M, Yorulmaz C. Evaluation of forensic cases admitted to Cerrahpașa Medical Faculty Emergency Service. Adli Bilimler Dergisi. 2002;1:21-6.

24. Turla A, Aydın B, Sataloğlu N. Mistakes and omissions in judicial reports prepared in emergency services. Ulus Travma Acil Cerrahi Derg. 2009;15:1804.

25. Seviner M, Kozacı N, Ay MO, Açıkalın A, Çökük A, Gülen M, et al. Analysis of judicial cases at emergency department. Cukurova Medical Journal (Çukurova Üniversitesi Tıp Fakültesi Dergisi). 2013;38:250-60.

26. Hakkoymaz H, Keten HS, Artuç S, Üçer H, Bozkurt S, Okumuş M, et al. Evaluation of medico-legal reports in respect of the Turkish penal code. J Kartal Tr. 2014;25:177-80

27. Karbeyaz K, Gündüz T, Balcı Y. Forensic medicine approach to bone fractures in the framework of the new Turkish penal code. Ulus Travma Acil Cerrahi Derg. 2010;16:453-8.

28. Çınar O, Acar YA, Çevik E, Kılınç E, Bilgiç S, Ak M, et al. Analysis of forensic cases in the 0-18 years age group that were presented to emergency department. Anatolian Journal of Clinical Investigation. 2010;4:148-51.

29. Bozkurt S. Evaluation of judicial reports which executing on emergency service and fixed deficiencies. Journal of Clinical and Analytical Medicine. 2015;6:331-4.

30. Demirci Ș, Günaydın G, Doğan UDKH, Aynacı Y, Deniz İ. The importance of practical applicatıon in preperation of forensic reports. Journal of Forensic Medicine. 2007;21:10-4

31. Güven FMK, Bütün C, Beyaztaș FY, Eren ȘH, Korkmaz İ. Evaluation of forensic cases admitted to Cumhuriyet university hospital. Meandros Med Dent J. 2009;10:23-8

32. Türkmen N, Akgöz S, Çoltu A, Ergin N. Evaluation of legal cases admitted to uludağ university medical school emergency department. Uludağ Medical Journal. 2005;31:25-9. 